\title{
Biocontrol Potential of Plant Growth Promoting Rhizobacterium (PGPR)- Pseudomonas against Plant Pathogenic Fungi
}

\author{
Ulfat Nazir $^{1 *}$, M. Y. Zargar ${ }^{1}$, Z. A. Baba ${ }^{1}$, S. A. Mir ${ }^{2}$, F. A. Mohiddin ${ }^{3}$ and N. A. Bhat ${ }^{3}$ \\ ${ }^{1}$ Division of Basic Sciences and Humanities, Faculty of Agricultural, Sheri Kashmir \\ University of Agricultural Sciences and Technology Kashmir, Jammu and Kashmir, India \\ ${ }^{2}$ Division of Agri. Statistics, Sheri Kashmir University of Agricultural Sciences and \\ Technology Kashmir, Jammu and Kashmir, India \\ ${ }^{3}$ MRCFC khudwani,, Sheri Kashmir University of Agricultural Sciences and Technology \\ Kashmir, Jammu and Kashmir, India \\ *Corresponding author
}

\section{A B S T R A C T}

\begin{tabular}{|c|c|}
\hline $\begin{array}{l}\text { Ke y } \\
\text { Biocor } \\
\text { Pseud } \\
\text { Antag } \\
\text { Fusari }\end{array}$ & $\begin{array}{l}\text { Soil borne plant pathogenic fungi are of major concern in agriculture. The plant diseases } \\
\text { need to be controlled to maintain the level of yield both quantitatively and qualitatively. } \\
\text { Biocontrol methods are safe, cost effective and eco-friendly. Understanding the } \\
\text { mechanism by which the biocontrol of plant diseases occurs is critical to the eventual } \\
\text { improvement and wider use biocontrol method. Many microbial antagonists such as }\end{array}$ \\
\hline Arti & \\
\hline $\begin{array}{l}\text { Accepted: } \\
18 \text { January } 2020 \\
\text { Available Online: } \\
10 \text { February } 2020\end{array}$ & $\begin{array}{l}\text { antagonistic activity of Pseudomonas against Fusarium oxysporum, Fusarium solani, } \\
\text { Pythium aphanidermatum and Sclerotina sclerotiorum. Pseudomonas exhibited the } \\
\text { maximum inhibition of growth of Fusarium oxysporum which is responsible for the wilt } \\
\text { disease in pea. }\end{array}$ \\
\hline
\end{tabular}

\section{Introduction}

Agriculture is heavily dependent on the use of chemical fertilizers and pesticides to achieve higher yields. This dependence is associated with problems such as environmental pollution, interruption of natural ecological nutrient cycling and destruction of agriculturally important biological communities. The use of bio resource to replace chemical fertilizers and pesticides is growing. In this context, plant growth promoting rhizobacteria (PGPR) are novel and potential tools to provide substantial benefits to agriculture (Sivasakthi et al., 2013).

Plant growth is influenced by many abiotic and biotic factors. Rhizosphere is a thin layer of soil immediately surrounding plant roots that is extremely important and active area for root activity and metabolism. A large number of organisms such as bacteria, fungi, protozoa co-exist in the rhizosphere, bacteria being the 
most abundant among them. However, there is a vast array of pathogenic microorganisms in the rhizosphere that cause diseases to the plants affecting their growth and yield. Fusarium has been recognized for a long time as being important plant pathogen (Booth, 1971; Nelson et al., 1983). Fusarium solani exists in the soil and attacks more than 2000 species of plants (Parmeter, 1970). Sudana et al., (1999) reported that ten millions of banana trees died because of wilt disease caused by fungus, Fusarium oxysporum within two years (2007-2009). Wilt caused by Fusarium oxysporum is one of the most devastating disease of pea. Pea wilt alone is responsible for $93 \%$ disease total yield in India (Sharma et al., 2006). Sclerotina sclerotiorum is another important plant pathogenic fungi that has been reported as a pathogen of more than 400 plant species around the world (Boland and Hall, 1994). White mold is a very serious problem in crops, especially when they are cultivated in contaminated wet soils and the weather is cool and wet (Reis and Lopes, 2007).

Plant growth promoting rhizobacteria (PGPR) are free living soil borne bacteria which enhance the growth of plant either directly or indirectly (kloepper et al., 1980). The direct mechanims involve nitrogen fixation, phosphorus solubilization, HCN production of phytohormones such as auxins, cytokinins, and gibberellins (Glick, 1995). Indirect mechanism includes combating various soil borne diseases that helps in better plant growth.

PGPR are indigenous to soil and the plant rhizosphere and play a major role in the biocontrol of the plant pathogens. They can suppress broad spectrum of bacterial, fungal and nematode diseases. The use of PGPR has become a common practice in many regions of the world, owing to significant control of the plant pathogens demonstrated by PGPR in the laboratory, greenhouse and field experiments. Recent progress in our understanding of their diversity, colonizing ability and mechanism of action, formulation and application should facilitate their development as reliable biocontrol agents against plant pathogens (Siddiqui, 2006).

Pseudomonas is the principal rhizobacterium with at tremendous potential for biological control against a wide range of plant pathogen (Kremer and Kennedy, 1996). Pseudomonas sp.is a ubiquitous bacterium in agricultural soils and has many traits that qualify it as PGPR. Many microbial antagonists have been reported to possess antagonistic activities against plant fungal pathogens, such as Pseudomonas fluorescens, Bacillus subtilis, Bacillus cereus, Trichoderma viride and Trichoderma harzianum. The successful control by these antagonists mainly against the diseases caused by different pathogenic genera viz. Fusarium, Pythium, Aspergillus, Alternaria, Rhizoctonai and Botrytisplays an important role in stimulating growth and enhancing yield traits of various crops(Gardener, 2006). This paper describes briefly the biocontrol potential of microbial antagonists particularly against plant fungal pathogens.

\section{Materials and Methods}

Antagonist activity of isolates of Pseudomonas against four fungi viz, Fusarium solani, Fusarium oxysporum, Pythium aphanidermatum and Sclerotinia sclerotiorumon potato dextrose agar (PDA) plates was examined by dual inoculation technique (Sakthivel et al., 1986). The fungal pathogen was inoculated on the plates containing potato dextrose agar medium and incubated at $28 \pm 2{ }^{\circ} \mathrm{C}$ for 72 hours. With the help of sterile cork borer, the disc of fungal growth from this plate was taken out and placed at the center of the fresh potato 
dextrose agar medium containing plate 24 hours old growth of bacterial isolate was then streaked on either side of the disc and kept for incubation at $28 \pm 2^{\circ} \mathrm{C}$ for 72 hours. After the incubation for 72 hours, the plates were visually observed for the inhibition of fungal pathogen by comparing with the control PDA plate inoculated with only fungal pathogen. Radial growth of the fungus was measured and inhibition percentage was calculated by the formula:

$\%$ inhibition $=\frac{(C-T)}{C} \times 100$

Where,

$\mathrm{C}=$ Colony diameter $(\mathrm{mm})$ of the control

$\mathrm{T}=$ Colony diameter $(\mathrm{mm})$ of the test plate

\section{Results and Discussion}

Isolates of pseudomonas were evaluated for antifungal activity against four fungal plant pathogens i.e. Fusarium solani, Fusarium oxysporum, Pythiuma phanidermatum and Sclerotina sclerotiorum. All tested fungal strains showed significant reduction in terms of radial growth after the treatment with Pseudomonas cultures, in comparison with the controls (table1).

The growth behaviour of test fungi with the culture of antagonist bacterium Pseudomonas sp. varied considerably. The culture of Fusarium oxysporum showed minimum colony diameter $(0.78 \mathrm{~mm})$ followed with Fusarium solani( $0.84 \mathrm{~mm}), \quad$ Pythium aphanidermatum $(0.86 \mathrm{~mm})$ and Sclerotina sclerotiorum $(0.98 \mathrm{~mm})$.The maximum inhibition in colony diameter was observed in Fusarium oxysporum(56.72\%), followed by Fusarium solani (51.28\%), Pythium aphanidermatum (40.16\%) and Sclerotina sclerotiorum (32.23\%) over control. Pseudomonas sp was found more effective for the control of Fusarium oxysporum which causes more and more loss in the productivity of pea crops in these areas. Our results corroborate with those of Singh et al., (2011).

Table.1 Effect of Pseudomonassp. on the radial growth of plant pathogenic fungi

\begin{tabular}{|l|l|c|c|}
\hline S.No & Name of the fungi & Colony diameter(in mm) & \% inhibition(in mm) \\
\hline $\mathbf{1}$ & Control & 60 & 00 \\
\hline $\mathbf{2}$ & Fusarium oxysporum & 0.78 & 56.72 \\
\hline $\mathbf{3}$ & Fusarium solani & 0.84 & 51.28 \\
\hline $\mathbf{4}$ & Pythium aphanidermatum & 0.86 & 40.16 \\
\hline $\mathbf{5}$ & Sclerotina sclerotiorum & 0.98 & 32.23 \\
\hline
\end{tabular}

In general, the potential antagonistic micro organisms selected from invitro tests often fail to effectively control plant disease in green house or field trails, particularly to soil borne pathogens. Several factors such as the type of content of organic matter, $\mathrm{pH}$, nutrients, and moisture level of the soil influence the efficacy of biocontrol agents. Due to the variations in the environment factors from one place to other places, sometimes, a good biocontrol agent under in vitro conditions, fails under in vivo conditions. To achieve the success, the environmental factors should be similar to those from which the biocontrol agents were isolated. Likewise, the method of the application can influence the success of the field trails. In general, there are three means of applying the antagonists for biocontrol, namely seed inoculation, vegetative part inoculation and soil inoculation. Field trail showed that the control efficiency of 
antagonist Burkholderia cepacias train N9523 against Phytophthora capsici was higher by soil-drenching them by wounded stem inoculation(lee et al., (1999); Dawar et al., (2008) tested the biocontrol potential of different microbial antagonists, Bacillus, thuringiensis, Rhizobium meliloti, Aspergillus niger and Trichoderma harzianum by coating the seeds with gumarabic, gulcose, sucrose and molasses. This method reduced successfully the infection of root rot fungi on okra and Sunflower, i.e Macrophomina phaseolina, Rhizoctonia solani and Fusarium spp. The highest suppression capacity was shown by seed treatment with $T$. harzianum using $2 \%$ of glucose.

\section{References}

Boland, G. J. and Hall, R. (1994). Index of plant hosts of Sclerotina sclerotiorum. Can J Plant Pathol, 16: 93-108.

Booth, C. (1971). The genus Fusarium. Commonwealth Mycological institute, Kew Surrey, England.237 pp.

Dawar, S., Hayat, S., Anis, M., Zaki, M.J. (2008).Effect of seed coating material in the efficiency of microbial antagonists for the control of root rot fungi on okra and sunflower. Pak. JBot. 40(3): 1268-1278.

Gardener, B.M. and Pal, K. (2006). Biological control of plant pathogens. The Plant Health Instructor doi: 10.1094/PHI-A2006-1117-02. APSnet: 1-25.

Glick, B. R. (1995). The enhancement of plant growth by free living bacteria. Canadia Journal of Microbiology, 41: 109-114.

Kloepper, J. W., Leong, J., Teintze, M. and Schroth, M. N. (1980). Enhancing plant growth by siderophores produced by plant growth promoting rhizobacteria. Nature 286: 885-886

Kremer, R.J., Kennedy, A.C. (1996). Rhizobacteria as biocontrol agents of weeds. Weed Technology, 10: 601609.

Lee, J. Y., Kim, B. S., Lim, S.W., Lee, B. K., Kim, C. H., Hwang, B. K. (1999). Field control of Phytophthora blight of pepper plants with antagonistic rhizobacteria and DL-amino nbutyric acid. Plant Pathol. J., 15(4): 217-222.

Nelson, P. E., Toussoun, T. A., Marasas, W. F. O. (1983). Fusarium species: An illustrated manual for identification the Pennsylvania state University press, University park and London.

Parmeter, J. R. (1970). Rhizoctonia solani biology and pathology university of California press, Barkeley, Los Angles and London. $255 \mathrm{Pp}$.

Reis, A. and Lopes, C. A. (2007). Principaisfungos de solo en Hortalicas: Epidemiologaemanejoin: Zambolim L; Lopes CA; PicancoNC;Costa,H (orgs). Manejointegrado de doencas e pragas:hortalicas. Vicosa: UFV.pp.189-224.

Sakthivel, N., Sivamani, E., Unnamalai, N. and Gnanamanickay, S. S. (1986). Plant growth promoting rhizobacteria in enhancing plant growth and suppressing plant pathogens. Journal of Current Science 55: 22-25.

Sharma, P., Sharma, K. D., Sharma, R. (2006), Genetic variability in pea wilt pathogen Fusarium oxysporumsp. pisiin north western Himalyas. Indian journal of biotechnology, 5: 298-302 pp.

Siddiqui, Z. (2006). PGPR: Prospective Biocontrol Agents of Plant Pathogens. Biocontrol. Biofertil. pp. 111-142.

Singh, S. K., Sheeba, R. D., Gupta, S., Rajendra, S. K., Verma, M. A., Siddiqui, A., Agarwal, P.K. (2011). Assessment of the role of the pseudomonas fluorescens as biocontrol agent against fungal plant 
pathogens. curr. Bot., 2(3): 43-46

Sivasakthi, S., Kanchana, D., Usharani, G., Saranraj, P. (2013). Production of plant growth promoting substance by Pseudomonas fluorescens and Bacillus subtilis isolated from paddy rhizosphere soil of Cuddalore district, Tamil Nadu, India. Int. J. Microbiol. Res. 4(3):227-233. Sudana, M., Arya, N., Suprapta, D.N. (1999). Study on banana wilt disease. Bali Agricultural extension service project.30 P.

\section{How to cite this article:}

UlfatNazir, M. Y. Zargar, Z. A. Baba, S. A. Mir, F. A. Mohiddin and Bhat, N. A. 2020. Biocontrol Potential of Plant Growth Promoting Rhizobacterium (PGPR)-Pseudomonas against Plant Pathogenic Fungi. Int.J.Curr.Microbiol.App.Sci. 9(02): 2516-2520.

doi: https://doi.org/10.20546/ijcmas.2020.902.286 